\title{
Post-Conviction Remedies in the Italian Criminal Justice System
}

\author{
Luca Lupária Donati \& Marco Pittiruti*
}

\begin{abstract}
The Italian Constitution expressly contemplates the possibility of a wrongful conviction, by stating that the law shall determine the conditions and forms regulating damages in case of judicial error. Therefore, it should come as no surprise that many provisions of the Italian Code of Criminal Procedure (CCP) deal with the topic. The aim of this article is to provide an overview of the post-conviction remedies in the Italian legal system by considering the current provisions of the $\mathrm{CCP}$, on the one hand, and by exploring their practical implementation, on the other.
\end{abstract}

Keywords: wrongful conviction, revision, extraordinary appeal, rescission of final judgment, res judicata

\section{Introduction}

In a recent television appearance, Italy's Ministry of Justice stated that 'innocent people don't end up in jail', ${ }^{1}$ signifying that national authorities are not always willing to admit the flaws of their criminal justice system.

With all due respect to Italy's Ministry of Justice, however, it is fair to state that although the Italian criminal justice system has undergone a deep renovation process, ${ }^{2}$ it is still far from being fully effective, especially

Luca Lupária is Full Professor of Criminal Procedure at Roma Tre University, Director of the Italy Innocence Project and President of the European Innocence Network. Marco Pittiruti is researcher of Criminal Procedure at Roma Tre University. This paper is, in its entirety, the result of a shared reflection of the Authors; however, Luca Lupária wrote paragraphs 1, 2, 3 and 4, while Marco Pittiruti wrote paragraphs 5, 6, 7 and 8 .

1. www.today.it/politica/bonafede-innocenti.html (last visited 26 December 2020).

2. As it is known, the Italian Code of Criminal Procedure of 1988 is a hybrid system, showing both inquisitorial and adversarial traits. Indeed, the reform that led to the new CCP has transposed into the Italian system the adversarial principles of orality, immediacy and confrontation: the accused has the right to be judged on the evidence that is formed during the trial in front of the trial judge; the accused also has the right to confront his accusers and cross-examine witnesses. Still, the CCP provides with multiple elements that reveal Italy's inquisitorial background: judges have the power to order evidence to be acquired ex officio, and they can also question witnesses and indicate to the parties new issues that need to be addressed. Moreover, the Italian appellate system has been left mainly untouched by the reform and still provides the parties with two additional 'instances' of judgment. See L. Lupária and M. Gialuz, 'The Italian Criminal Procedure: Thirty Years after the Great Reform', 1 Roma Tre Law Review 26 (2019); L. Marafioti, 'Italian Criminal Procedure: A System Caught Between Two Traditions', in J. with regard to wrongful convictions. ${ }^{3}$ In fact, between 1991 and 2019, Italy had to face at least 191 cases of wrongful conviction, ${ }^{4}$ a number that falls short of being representative of the real proportion of wrongful convictions. Indeed, a reversal of a previous final judgment (this being, strictu sensu, a wrongful conviction) can occur only in exceptional circumstances. Furthermore, the Ministry of Justice does not provide official data concerning wrongful convictions.

In this article, we provide an overview of the post-conviction remedies in the Italian legal system, by considering the current provisions of the Italian Code of Criminal Procedure (from now on, CCP), on the one hand, and by exploring their practical implementation, on the other.

We start by examining the Italian Constitution, which specifically considers the occurrence of a deviation between historical truth and judicially ascertained truth ${ }^{5}$ (Art. 24, para. 4, of the Constitution). We then analyse the main remedy set forth by the criminal procedure rules to overcome a final judgment - i.e. the revision ${ }^{6}-$ and the compensatory measures that follow the acquittal of the defendant after the revision trial. ${ }^{7}$ Lastly, we take a closer look at the remedies set forth by the CCP for 'procedural' injustices that may have occurred during the trial, as indirect means to protect the wrongfully convicted. ${ }^{8}$

Jackson, M. Langer \& P. Tillers (eds.), Crime, Procedure and Evidence in a Comparative and International Context (2008) 81.

3. On the issue of wrongful conviction in Italy, see L. Lupária, 'Cultura della prova ed errore giudiziario: il processo penale in discussione', in L. Lupária, L. Marafioti \& G. Paolozzi (eds.), Errori giudiziari e background processuale (2017) XI. See also L. Lupária and C. Greco, 'Unveiling Wrongful Convictions Between the US and Italy: Cross-Learning From Each Other's Mistakes', 1 Wrongful Conviction Law Review 101 (2020).

4. www.errorigiudiziari.com/errori-giudiziari-quanti-sono/ (last visited 26 December 2020). It should be noted that these are not official figures provided by the Ministry of Justice but data collected and processed by the site's curators.

5. See infra, § 2 .

6. See infra, $\S 3,4$ and 5 .

7. See infra, $\S 6$.

8. See infra, § 7 . 


\section{Post-Conviction Remedies and the Italian Constitution}

Article 24, paragraph 4, of the Constitution provides that 'the law shall determine the conditions and forms regulating damages in case of judicial errors'. ${ }^{9}$ A corollary to this rule is that, strictly speaking, only an erroneous verdict concerning the existence of the criminal liability of the accused can be defined as a judicial error. Indeed, even though the acquittal of a culprit can broadly be considered an 'error', there is no damage to be regulated in this case, so much so that the CCP expressly prevents a new criminal proceeding to be held for the same criminal act. ${ }^{10}$

The reference made by Article 24, paragraph 4, of the Constitution to the 'conditions and forms regulating damages' could be interpreted as allowing the victim of the wrongful conviction only the right to receive monetary compensation for the injustice suffered. However, in order to recognise the right to monetary compensation, a system must be equipped with a special procedural tool aimed at identifying any errors crystallised in a judgment that has now become res judicata, and as such no longer subject to ordinary appeal. ${ }^{11}$

At the same time, the provision of an extraordinary instrument of appeal represents in itself a 'condition and way' of redressing the judicial error. ${ }^{12}$ With this in mind, Article 24, paragraph 4, of the Constitution integrates the protection offered by the three preceding paragraphs, aimed, respectively, at ensuring that 'anyone may bring cases before a court of law in order to protect their rights' (Art. 24, para 1), that 'defense is an inviolable right at every stage and instance of legal proceedings' (Art. 24, para. 2) and that 'the poor are entitled by law to proper means for action or defense in all courts' (Art. 24, para. 3). Therefore, Article 24, paragraph 4, of the Constitution grants the victim of judicial error two distinct rights: the right to act for the identification and removal of the error and the right to mone-

9. This and the following quotes from the Italian Constitution in English are taken from Constitution of the Italian Republic, Senato della Repubblica, translation supervised by the Senate International Affairs Service, 2018, www.senato.it/application/xmanager/projects/leg18/ file/repository/relazioni/libreria/novita/XVII/COST_INGLESE.pdf (last visited 26 December 2020).

10. Art. 649, para. 1, CCP: 'the accused person who has been dismissed or convicted by a judgment or criminal decree that has become final shall not be prosecuted again for the same offence, even if his conduct is considered differently in terms of legal definition, stage of the offence or circumstances ...'. This and the following quotes from the Italian Code of Criminal Procedure in English are taken from M. Gialuz, L. Lupária \& F. Scarpa (eds.), The Italian Code of Criminal Procedure, 2nd ed. (2017).

11. Art. 648 CCP: "judgments delivered at trial which are not subject to an appellate remedy other than revision are final. If an appellate remedy may be invoked, the judgment becomes final upon expiry of the time limit set to lodge the remedy or to appeal the order declaring his inadmissibility. In case of an appeal to the Court of Cassation, the judgment becomes final from the day of delivery of the order or judgment rejecting the appeal or declaring it inadmissible ...'.

12. See M. D'Aiuto, 'La riparazione dell'errore giudiziario', in L. Lupária (ed.), L'errore giudiziario (2020) 723. tary compensation for the unfair limitation of personal liberty deriving from the unjust conviction. ${ }^{13}$

The CCP implements the constitutional precept along the two aforementioned lines. On the one hand, Article 629 CCP sets forth the so-called revision, i.e. an extraordinary appeal aimed at the annulment of the unjust conviction, while on the other, Article $643 \mathrm{CCP}$ provides for an economic compensation for the damages suffered as a result of the wrongful conviction.

Furthermore, in the last twenty years, the principle of intangibility of the res judicata has been challenged by new laws increasingly expanding the instruments in favour of the convicted after the final judgment. We are referring to the 'Extraordinary appeal due to a factual error' under Article 629-bis CCP, by which the not otherwise amendable perceptive error of the Court of Cassation can be corrected, and to the 'Rescission of final judgment', an extraordinary appeal aimed at removing the final judgment in case of a trial conducted entirely in the absence of the accused, who was unaware of the ongoing proceeding.

Each of these tools has its own ratio and discipline. It is therefore advisable to examine them separately.

\section{The Basic Features of Revision}

\subsection{The Mutual Relationship between Revision and Judicial Error}

Revision is the main tool at the disposal of a convicted person to ascertain a judicial error. Through this extraordinary appeal, it is possible to request that final (i.e., irrevocable) judgments of conviction be removed because of the existence of new cognitive elements that can reveal the judge's faulty evaluation of the facts contained in the final decision, thus leading to its reversal. Therefore, the hypotheses of revision envisaged by the CCP are intended to remedy a 'substantial' injustice of the ruling, that is to say an error in the reconstruction of the historical event, leading to an unjust overcoming of the presumption of innocence. ${ }^{14}$

Between revision and judicial error, there is a relationship that goes in a 'two-way direction'. ${ }^{15}$ On the one side, the alleged error is a prerequisite for the request of revision, while, on the other side, the judicial error acquires legal significance only following its assessment through the revision judgment. With this in mind, we can affirm that revision represents a 'system security

13. See M. Gialuz, 'Remedies for Miscarriage of Justice in Italy', in L. Lupária (ed.), Understanding Wrongful Conviction. The Protection of the Innocent Across Europe and America (2015) 117.

14. Instead, the procedural injustice remains outside the operational sphere of the revision. See P. Troisi, L'errore giudiziario tra garanzie costituzionali e sistema processuale (2011), at 109.

15. See R. Del Coco, 'Giudicato, progresso scientifico e prova nuova. Limiti e prospettive del giudizio di revisione', in L. Lupária, L. Marafioti \& G. Paolozzi (eds.), Errori giudiziari e background processuale (2017) 101. 
mechanism', ${ }^{16}$ capable of guaranteeing the individual's personal freedom, in cases where an antinomy between the definitive statement of guilt pronounced and the historical truth is ascertained. In other words, the Italian legislature has sacrificed the certainty of the irrevocable judgments to 'meet the ineluctable requirements of truth and justice'. ${ }^{17}$

In the wake of a consolidated Italian legal tradition, the current CCP provides for revision as a remedy operating only in favour of the convicted person. The request can be proposed 'at any time' (Art. 629 CCP) by the convicted person or his or her next of kin or person's guardian; if the convicted person is deceased, by his heir or a next of kin; or, finally, by the Prosecutor General attached to the Court of Appeal in whose district the judgment of conviction was pronounced (Art. $632 \mathrm{CCP}$ ).

The judgments of conviction and the judgments of application of punishment upon request, as well as final criminal decrees of conviction, can be subject to revision (Art. 629 CCP) once they have become irrevocable, even if the sentence has already been executed or extinguished (Art. 629 CCP).

The conviction's erroneousness must be evaluated against the symptoms enunciated by the legislature to verify its possible substantial injustice. Indeed, only the error that emerges from new facts can justify the overcoming of a final judgment, thus avoiding that the review may turn into a fourth degree of judgment ${ }^{18}$ based on a mere re-evaluation of the same factual elements underlying the previous judgment (Art. 637, para. 3, CCP).

\subsection{The Revision Cases}

The revision cases are strictly established by Article 630 CCP: $a$ ) if the facts underlying the judgment or the criminal decree of conviction are incompatible with those established in another final criminal judgment issued by the ordinary court or by a special court; $b$ ) if the judgment or criminal decree of conviction has based its decision on a judgment issued by the civil or administrative court and subsequently revoked, if a decision has been taken on one of the preliminary issues provided for in Article $3 \mathrm{CCP}^{19}$ or in one of the issues provided for in Article $479 \mathrm{CCP} ;{ }^{20} c$ ) if new evidence is found or discovered after conviction and, either inde-

16. See G. Dean, La revisione (1999), at 13 and F. Callari, La revisione: la giustizia penale tra forma e sostanza (2010), at 23

17. Gialuz, above n. 13, at 121

18. See A. Presutti, 'La revisione del giudicato penale tra impugnazione straordinaria e quarto grado di giudizio', 3 Studium iuris 245 (2009).

19. Pursuant to Art. $3 \mathrm{CCP}$, 'if the decision depends upon the resolution of a dispute on either family status or citizenship, if the issue is serious and a civil action is already in progress, the court may suspend the trial until the judgment settling the case becomes final'.

20. Pursuant to Art. $479 \mathrm{CCP}$, 'if the decision on the existence of the offence depends on the resolution of a particularly complex civil or administrative controversy, which is already being prosecuted before a competent court, the criminal court may order suspension of the trial. The trial may be suspended if the law imposes no limits on evidence demonstrating the controversial subjective stance in civil or administrative proceedings. The trial shall be suspended until the case is closed with a final judgment' pendently or together with already assessed evidence, proves that the convicted person must be acquitted; ${ }^{21} d$ ) if it is proven that the judgment of conviction has been delivered on the basis of or as a consequence of false documents or statements provided during the trial or of any other criminal act deemed an offence by the law. ${ }^{22}$

The aforementioned hypotheses must be integrated with another one created by the jurisprudence. With regard to Article $630 \mathrm{CCP}$, the Constitutional Court ${ }^{23}$ has also allowed request for revision when the reopening of the proceeding is necessary to comply with a final judgment of the European Court of Human Rights. However, this hypothesis shares with those provided for by Article 630 CCP only its nature of extraordinary appeal, whereas it differs significantly from a functional point of view. In fact, filing a request for the 'European revision' does not imply giving the Court new evidence proving that the convicted person must be acquitted. Nonetheless, the 'European revision' can be considered an indirect remedy for judicial errors, since it is a tool that allows an atypical regression of the process to the merit phase.

Conversely, the 'lowest common denominator'" revision cases established by the CCP is the presentation of new elements that might prove, if ascertained, that the convicted person must be acquitted ${ }^{25}$ in short, new cognitive elements must emerge beyond those already examined.

At the same time, a consideration of all the acquittal formulas provided for by the CCP highlights that the revision is allowed not only if the new elements - alone or together with evidence already gathered in the previous judgment - prove the innocence of the convicted, but

21. Among the new evidence that can be brought to the attention of the Court of Appeal in a request for revision, an important role is played by the testimony. An exemplary case is offered by the judicial error concerning Giuseppe Gulotta. In 1976, Gulotta was arrested and later sentenced to life imprisonment on charges of participating in the killing of two carabinieri. Gulotta was subjected to different forms of torture while he was interrogated without the assistance of a lawyer and finally confessed to the double murder. In 2012, the Court of Appeal of Reggio Calabria eventually revoked Gulotta's conviction after his application for revision, following the testimony of a carabiniere, who had assisted at the tortures that led to the extorted confession. Testimony also helped to discover the wrongful conviction of Domenico Morrone for the murder of two minors. Even though Morrone had an alibi, the judges had convicted him because of witnesses reporting to have seen him committing the murder to the criminal police. The judges did not consider the fact that, during the trial, a few of those witnesses retracted the statements previously made, admitting that they were forced to indicate Morrone as the material author of the crime under threat of retaliation and physical violence by the criminal police. Finally, during the revision trial, two collaborators of justice indicated that Morrone was extraneous to the criminal facts and reported that they had gained such information from the real murderer, whose identity was revealed.

22. To file a request for revision based on the hypothesis referred to in Art. 630 , let. d), CCP it is necessary that the false statement (e.g. false testimony) or the criminal act deemed an offence by law (e.g. slander) that led to the wrongful conviction have been ascertained by a final judgment; if a new testimony emerges instead, it will be possible to propose a request for revision pursuant to Art. 630, let. C), CCP.

23. See Constitutional Court., 7 April 2011, no. 113

24. Gialuz, above n. 13, at 125.

25. The reasons and evidence justifying the revision must be specifically indicated in the request: Art. 633, para. 1, CCP. 
also if they present a reasonable doubt about his guilt. From this it follows that it is not possible to file a request of partial revision, i.e., to obtain a conviction for a lesser offence (as was permitted under Art. 554 of the 1930 CCP), or to achieve the application of a mitigating circumstance.

\subsection{The Revision Proceeding}

The system envisaged by the 1988 CCP presents further innovative features compared with those outlined by the 1930 CCP, which contemplated a clear separation between iudicium rescindens and iudicium rescissorium. The former was mandatory and took place before the Court of Cassation, while the latter occurred only if the Court, having assessed that the request was not inadmissible or manifestly groundless, annulled the sentence, subordinate to the condition that the judge to whom the proceeding was referred would acquit the convicted person.

Conversely, in the 1988 CCP, both phases were entrusted to the Court of Appeal. In short, once the request for revision is submitted, the Court of Appeal - which in Italy is composed solely of professional judges makes an inaudita altera parte preliminary examination of the admissibility of the application, to exclude manifest groundlessness and to test compliance with the requirements set by the CCP. In other words, the judges are required to make a prognostic evaluation of the suitability of the elements adduced to determine, if afterwards ascertained, the acquittal of the interested party. To this end, the novum must be weighed, also in terms of its reliability, persuasiveness and congruence against the evidence already assessed in the previous judgment. ${ }^{26}$

In the delicate phase of preliminarily examining the admissibility of the application, the risk of trespassing into an evaluation of the merit of the request may be at hand. ${ }^{27}$ This explains why the norm must be interpreted in the sense that the preliminary assessment of manifest groundlessness should concern only the relevance of the evidence. $^{28}$

If the Court of Appeal declares the inadmissibility of the request for revision, the applicant can appeal to the Court of Cassation. If the appeal is accepted, the Court of Cassation shall refer the revision trial to a different Court of Appeal (Art. 634, para. 2, CCP).

If the request for revision is deemed admissible, the revision judgment can take place, for which the same rules provided for the trial apply (Art. 636 CCP). During this phase, the enforcement of the sentence can be discretionarily suspended by the Court of Appeal if there is a positive prognosis regarding the acceptance of the application.

26. Court of Cassation, Sec. I, 5 March 2013, Scimone, in C.E.D. Cass., no. 256157.

27. See Del Coco, above n. 15, at 106; Dean, above n. 16, at 93.

28. See G. Canzio, 'La revisione del processo: gli effetti del sopraggiungere di nuove prove rese possibili dal progresso scientifico', in A. Balsamo and R. Kostoris (eds.), Giurisprudenza europea e processo penale italiano (2008) 481.
If the request for revision is accepted, the Court revokes the judgment of conviction or the criminal decree of conviction and orders the acquittal, specifying its reason in the operative part of the judgment (Art. 637, para. 1, CCP). The ruling is accompanied by restorative measures, such as the order to refund the acquitted of the paid sums inherent in the criminal proceeding; the affixion of an extract of the judgment in the municipality where the sentence was pronounced, as well as where the acquitted last resided; the publication of an extract of the judgment in a newspaper indicated by the acquitted.

If, on the contrary, the application is rejected, the applicant can appeal to the Court of Cassation (Art. 640 CCP) or file another application based on different elements (Art. 641 CCP). The judgment of the Court of Appeal may be appealed to the Court of Cassation to challenge any errores in procedendo (Art. 606, let. $c-d$, CCP), errores in iudicando (Art. 606, let. $b$, CCP) or the fault of motivation (Art. 606, let. $e$, CCP). ${ }^{29}$

\section{The Notion of New Evidence}

The most common revision hypothesis in the Italian practice is undoubtedly provided for by Article 630, paragraph 1, lett. c) CCP, concerning the occurrence of 'new evidence'. ${ }^{30}$

Consequently, this aspect has been at the core of numerous jurisprudential reconstructions aimed at explaining its meaning, alternatively enlarging or reducing the application perimeter of the revision.

Such lack of hermeneutical consensus derives from the fact that Article 630 CPP does not clarify whether the notion of new evidence must also include, in addition to the classical hypothesis of the noviter repertae evidence (i.e. evidence that emerged only after the judgment had

29. According to Art. 606 CCP, an appeal to the Court of Cassation may be lodged if it is based on the following arguments: ' $a$ ) the court exercises a power that is granted by law to legislative or administrative bodies or not allowed to public authorities; b) failure to comply with or misapplication of criminal law or other legal rules which must be considered in the application of criminal law; c) failure to comply with the procedural rules established under penalty of nullity, exclusion of evidence, inadmissibility or expiry; d) decisive evidence is not gathered, when a party has requested its gathering also during the trial evidentiary hearing, exclusively in the cases provided for in Art. 495, para. 2; e) the grounds of the judgment are lacking, contradictory or manifestly illogical, when the defect results from the text of the appealed decision or from other documents of the proceedings specified in the arguments for the appeal to the Court of Cassation'.

30. Among the most recent new evidence that praxis deems suitable to establish a revision request, the following can be mentioned: health documentation suitable for integrating an alibi test (Court of Cassation, Sec. V, 21 June 2019, Nikolli, in C.E.D. Cass., no. 277538); testimonial statements suitable to overturn the accusatory construct (Court of Cassation, Sec. II, 14 February 2019, Camassa, in C.E.D. Cass., no. 276437); interrogation made by the convicted person before the judicial authority of another state (Court of Cassation, Sec. VI, 23 January 2018, Fraquelli, in C.E.D. Cass., no. 272517); a psychiatric report on the convicted preceding the celebration of the trial that ended with the assertion of his responsibility (Court of Cassation, Sec. VI, 10 May 2017, Buzzerio, in C.E.D. Cass., no. 270414). 
become final), also the noviter productae evidence (i.e. evidentiary material that, although pre-existing, was not gathered in the trial), or even the noviter cognitae evidence (i.e. elements that were gathered during the trial but were not assessed by the judge).

Initially, jurisprudence endorsed the extensive interpretation that all the three aforementioned species should be considered as new evidence, on the basis that they had not been previously evaluated. ${ }^{31}$ But practice soon led to different conclusions, starting from the acknowledgment that revision is an extraordinary remedy. It followed that only evidence that had remained materially unrelated to the irrevocably defined process (i.e. noviter repertae and noviter productae evidence) could fall within the concept of novum. ${ }^{32}$ This was probably owing to the 'traditional necessity of stability of the judicial decisions and of protection of the normative status quo related to criminal justice'. ${ }^{33}$ As a result, the possibility to file a revision request was narrow.

However, this prospect soon underwent a new change, on the correct assumption that any evidence that was not 'gnoseologically externalised in the grounds of the judgment' 34 is characterised by novelty, whereas the reason for the omitted acquisition is irrelevant. Hence, the most recent orientation that allows admission in the revision of any evidence that escaped the appreciation of the judges, therefore includes in the notion of 'new' evidence all the three types of evidence described, i.e. the noviter repertae, the noviter productae and the noviter cognitae. ${ }^{35}$

\section{The Boundaries of Revision Based on New Scientific Evidence}

\subsection{The Expansion of Revision Based on the Application of New Scientific Methods to Materials Already Acquired}

The theme just outlined intersects with another one of great practical relevance, that is, the boundaries of revision requested on the basis of new scientific evidence. ${ }^{36}$ As is well known, such evidence, which employs new,

31. See Court of Cassation, Sec. II, 27 March 1992, Barisano in Cass. pen., 1994, 1607.

32. Court of Cassation, Joint Chambers, 11 May 1993, Ligresti, in C.E.D. Cass., no. 193421.

33. See L. Lupária, 'Rethinking the Approach to Wrongful Convictions in Europe: Some Preliminary Remarks', in Id. (ed.), Understanding Wrongful Conviction. The Protection of the Innocent across Europe and America (2015) 1, at 4.

34. Court of Cassation, Joint Chambers, 26 September 2001, Pisano, in C.E.D. Cass., no. 220443

35. However, the evidence initially admitted in the trial and subsequently excluded cannot be counted among 'new evidence' suitable for revision, on the grounds that the exclusion of previously admitted evidence does imply that such evidence is superfluous (Court of Cassation, Sec. III, 16 May 2019, A., in C.E.D. Cass., no. 277174).

36. For an overview of the broad subject of scientific evidence, see G. Canzio and L. Lupária, Prova scientifica e processo penale (2017). highly specialised and possibly controversial scientific methods and technical tools, is the result of the continuous evolution of scientific and technological knowledge. This could potentially have a negative impact on the firmness of the res judicata. ${ }^{37}$ In this regard, it is worth mentioning that Italian case law generally deems admissible a request for revision based on the occurrence of new evidence that requires technical investigation, whereas greater difficulties emerge in relation to new screenings of previously acquired material based on assessments that were not carried out during the trial.

Initially, the obstacle to a consideration of such elements of knowledge during the revision resided in the prohibition pursuant to Article 637, paragraph 3, CCP, ${ }^{38}$ since the new assessments would have resulted in a critical evaluation of data already examined, at the risk of turning the extraordinary appeal into a new degree of judgment. However, behind this orientation, one can detect an outdated conception of science as an immutable and all-comprehensive type of knowledge, while the reverse is true: science and technology are characterised by ongoing progress. With this in mind, the antinomy between the spatio-temporal limitation of the criminal trial and the continuous scientific and technical advancements must necessarily be composed in the sense of an adaptation of the former to the latter, embracing the principle of favor innocentiae. ${ }^{39}$

At the turn of the century, once the noviter cognitae evidence was included with full right in the notion of new evidence, the time was ripe for a corresponding expansion of revision based on the application of new scientific methods to materials already acquired. ${ }^{40}$ Therefore, pronouncements began to be made by the Court of Cassation in which the novelty of the evidence was identified not only in the object of the assessment, but also in the use of a scientific method of analysis dif-

37. See F. Caprioli, 'La scienza "cattiva maestra": le insidie della prova scientifica nel processo penale', in 9 Cass. pen. 3520 (2008).

38. Ex multis see Court of Cassation, Sec. I, 23 February 1998, Nappi, in C.E.D. Cass., no. 210022.

39. See G. Paolozzi, 'Relazione introduttiva', in L. Lupária, L. Marafioti \& G. Paolozzi (eds.), Dimensione tecnologica e prova penale (2019) 17.

40. See Court of Cassation, Sec. V, 14 May 1997, Cavazza, in C.E.D. Cass., no. 208546. Paradigmatic is the case of the judicial error that struck Pietro Paolo Melis, whose innocence was recognised thanks to an expert witness in sound-biometric analysis. Melis was arrested and later convicted for kidnapping a woman because of the expert evidence gathered in the first instance trial. In particular, the experts attributed to Melis the voice of an unknown interlocutor wiretapped in a car belonging to another person who was involved in the same kidnapping. The expert evidence gathered in the revision trial, using new and more reliable techniques than those employed during the first instance trial, clarified that, because of a persistent noise in the tape background, the unknown interlocutor voice could not be attributed with certainty to Melis, who was finally acquitted after a revision request. The erroneous interpretation of the wiretapping results links the case of Melis to that of Angelo Massaro. A wiretapped conversation between Massaro and his wife led to his conviction to life imprisonment for the crimes of kidnapping, murder and concealment of the corpse. In fact, in such conversation, Massaro pronounced the word muers (i.e. something very bulky), which was misinterpreted by the judges as muert, that is, a dead man. In the end, he was acquitted thanks to the testimony of Massaro's wife (who did not testify in the first instance trial) and mother, who helped clarify the real content of the wiretapped conversation. 
ferent from the one employed in the trial, if this could produce new factual elements. Subsequently, the Court of Cassation even provided some guidelines to assess the admissibility of the request for revision based on new scientific evidence:

a) the appreciation of the novelty of the method introduced; b) the evaluation of its scientific value; c) the application of the new scientific method to the probative results already examined; d) the judgment of novelty of the results obtained through the new method; e) the assessment of those results in the context of evidence already collected in the trial, in order to establish whether they are suitable for determining a different sentencing. ${ }^{41}$

This represented a decisive step that paved the way for further developments concerning the institute of revision. Indeed, by anchoring the novelty to the new factual elements, a significant broadening of the horizon relating to the protection of the convicted was achieved. This is the case, for example, of a scientific method already existing at the time of the trial but not applied in those circumstances but suitable for an acquittal. If it is true that, viewed in these terms, revision runs the risk of transforming itself into a new degree of judgment, it is equally true that the convicted cannot be made to pay for the wrong choices eventually made by an expert or by a lawyer.

\subsection{Learning from the Italian Lesson:}

Discretionary Jurisprudential Choices and Favor Innocentiae

We should be aware that there is still a long way to go before the shared notion of new evidence is reached. Extensive pronouncements, which expand the revision's field of application, stand side by side with judgments pursuing the opposite. Let us consider what happens in the field of digital evidence: here, jurisprudence denies the possibility of a revision based on a new analysis of the computer data already gathered in the trial, even if conducted through a different digital forensics technique. $^{42}$ In fact,

a different and new technical-scientific evaluation of the data already known to the expert and the judge does not constitute new evidence ..., since it is in all respects a different assessment of elements already known and evaluated in the trial, as such inadmissible ... ${ }^{43}$

41. Court of Cassation, Sec. I, 8 March 2011, Ghiro, in C.E.D. Cass., no. 249864.

42. For an exhaustive treatment of the use of digital forensics in the criminal trial, see G. Ziccardi, 'L'ingresso della computer forensics nel sistema processuale italiano: alcune considerazioni informatico-giuridiche', in L. Lupária (ed.), Sistema penale e criminalità informatica. Profili sostanziali e processuali nella Legge attuativa della Convenzione di Budapest sul cybercrime (L. 18 marzo 2008, n. 48) (2009) 166.

43. Court of Cassation, Sec. III, 17 March 2016, no. 18706, A., Unpublished.
Along the same lines, in the broader field of scientific evidence, it has been recently ascertained that new analyses of the same data do not fall under Article 630, paragraph 3, lett. c) CCP. The case in question concerned epidemiological studies on the possible causal link between exposure to asbestos and the onset of lung cancer. If such studies, despite reaching different assessments, do not deny the scientific validity of the knowledge implemented in the previous judgment, as stated by the Court of Cassation, the request for revision must be rejected, as it results in an alternative reading of the factual data. ${ }^{44}$

In the light of the foregoing, the Italian experience proves that the concept of new evidence on which revision rests needs to be better defined by the legislature and that it should expressly include, in addition to the noviter repertae evidence, also the noviter productae and noviter cognitae evidence. Undeniably, a non-fixed notion of new evidence is likely to produce unjust disparities between convicted persons. At present, the admissibility of the revision request depends essentially on the discretionary choice of the judges in charge of the single case, who make an 'ideological' choice between the two poles represented, on one side, by the protection of the final judgment and, on the other, by the need to remedy the wrongful conviction. On the contrary, we support the view that if any type of evidence makes it possible to detect a wrongful conviction, the latter should not 'remain drowned in the sea of res judicata' ${ }^{45}$

\section{The Compensation of the Judicial Error}

Article 643 CCP entitles the victim of a miscarriage of justice to 'a compensation proportionately to the duration of the sentence or confinement that may have been served and to the personal and family consequences resulting from the conviction', ${ }^{46}$ The request can be proposed by the victim (or, in the event of his death, by one of the heirs) within two years of the time the judgment of revision has become final. The Court of Appeal decides on the request in chambers. ${ }^{47}$

44. Court of Cassation, Sec. III, 21 May 2019, Lemetti, in C.E.D. Cass., no. 276594.

45. G. Leone, 'Il mito del giudicato', in 1 Rivista di diritto processuale penale 167, at 197 (1956)

46. Lastly, on the subject, A. Gentile, 'La riparazione dell'errore giudiziario', in L. Lupária, L. Marafioti \& G. Paolozzi (eds.), Errori giudiziari e background processuale (2017) 153. See also L. Scomparin, 'Errore giudiziario (riparazione dell')', XII Digesto penale (1997) 319; E. Turco, L'equa riparazione tra errore giudiziario e ingiusta detenzione (2007).

47. Art. 127 CCP: 'if it is necessary to proceed in chambers, the court .. shall set the date of the hearing and serve a notice on the parties and other persons concerned, as well as their lawyers. ... The Public Prosecutor, the other addresses of the notice and the lawyers shall be heard if they appear in court. ... The hearing shall take place without the presence of the public'. 
The repairable damage, to be estimated with an equitable judgment, ${ }^{48}$ includes all forms of material and non-material damages and can be liquidated by payment of a sum of money or by setting up a life annuity or, lastly, by admittance to an institution at the expense of the state.

The legal framework of reparation has long been disputed in doctrine and jurisprudence, with regard to its nature of restitution or indemnification.

In the aftermath of the entry into force of the Constitution, the request was believed to descend from the state's liability for an unlawful act; ${ }^{49}$ however, this led to objections that the res judicata - regardless of its accordance with historical truth - is always lawful, unless it is the result of wilful misconduct or of gross negligence on the part of the magistrate. ${ }^{50}$ And yet the equation between compensation and indemnification remained unsatisfactory. Indeed, indemnification derives from liability for a lawful act, that is to say, a damage to the subjective interest made in the name of a higher interest; but it is in the community's interest that the restrictions of personal freedom be anchored in the guilt of the accused. ${ }^{51}$

Hence, the institute under analysis should be granted an autonomous physiognomy, in which the restitutio in integrum responds to both a solidarity perspective - that is, compensating the prejudices suffered by the wrongfully convicted - and the necessity of safeguarding the inner balance of the legal system. ${ }^{52}$

Compensation is assigned if certain positive and negative conditions exist. As for the former, the applicant must have been acquitted after a revision trial. The repair is due in case of either a full acquittal or insufficient, contradictory or lacking proof that the criminal act occurred (Art. 530 CCP) and judgment of non-prosecution (Art. 529 CCP).

The second requirement is that the miscarriage of justice must not have been a consequence of intentional misconduct or gross negligence by the convicted, according to the fundamental principle of self-responsibility, ${ }^{53}$ implying that the victims of a miscarriage of justice are only those who have not contributed to determining it. As clarified by jurisprudence, intentional misconduct includes the case of a person who falsely blames himself for the crime or creates false evidence against himself, while gross negligence includes those conducts characterised by carelessness, neglect and

48. See M.G. Coppetta, La riparazione per ingiusta detenzione, (1993), at 299.

49. V. Cavallari, 'La riparazione degli errori giudiziari secondo l'art. 24, ultimo comma, della Costituzione', in I Giustizia penale 276 (1954).

50. P. Troisi, 'La riparazione dell'errore giudiziario', in G. Dalia, P. Troisi \& R. Troisi (eds.), I rimedi al danno del processo (2013) 5, at 18.

51. See G. Tranchina, 'Riparazione alle vittime degli errori giudiziari', Novissimo digesto italiano 1194 (1968)

52. R. Vanni, Nuovi profili della riparazione dell'errore giudiziario (1992), at 51. Lastly, in jurisprudence, on the presence of both a compensation and an indemnity component in the reparation for miscarriage of justice, Court of Cassation, Sec. IV, 4 April 2018, Montalto, in C.E.D. Cass., no. 273403.

53. See Gialuz, above n. 13, at 133. indifference for the consequences of one's own actions on the evolution of the trial. ${ }^{54}$

As noted previously, a total of 191 compensation requests pursuant to Article 643 CCP were accepted in Italy between 1991 and 2019, resulting in an expenditure by the state of close to 66 million euros. ${ }^{55}$ However, we do not know how many individuals acquitted following a revision did not submit a request for compensation or have seen their submission rejected.

The all in all limited number of accepted requests must also be ascribed, at least partly, to a certain reluctance by the Italian judges to acknowledge compensation. In fact, leveraging on the indeterminacy of the notion of intentional misconduct or gross negligence pursuant to Article 642 CCP, it was argued, for example, that compensation is not due to the person who, during the trial, kept silent about the defensive arguments that could have been suitable to determine his acquittal. ${ }^{56}$ In addition, Courts of Appeal often deny compensation in the event of inefficiencies and errors by the technical defence, such as failure to present an appeal ${ }^{57}$ or in case of a false alibi. $^{58}$

In short, in the Italian system, the institute of revision has experienced a progressive - albeit slow - expansion in practice; nonetheless, with regard to the economic reparation side of the miscarriage of justice, there is an inborn reluctance on the part of the judges to acknowledge it, in the name of an undue protection of state finances. We should, on the contrary, consider that economic compensation represents an inevitable corollary to the detected erroneousness of judicial ruling, as already foreseen by Article 24, paragraph 4, of the Constitution.

\section{Procedural 'Injustice' and Wrongful Conviction}

\section{1 'Extraordinary Appeal Due to a Factual Error' as an Indirect Remedy for Miscarriage of Justice}

It has been pointed out that revision aims at amending a 'substantial' miscarriage of justice, namely a judicial error that concerns the factual truth underlying the sentence.

Still, in order not to be invalidated by error, a decision must comply with the set of procedural guarantees, besides truthfully ascertaining the facts of the case. ${ }^{59}$

54. Court of Cassation, Sec. III, 17 May 2016, Attaguile, in C.E.D. Cass. no. 268494.

55. www.errorigiudiziari.com/errori-giudiziari-quanti-sono/ (last visited 26 December 2020).

56. Court of Cassation, Sec. III, 12 February 2009, Ministero Economia e Finanze in proc. Grande, in C.E.D. Cass., no. 243251.

57. See Court of Cassation, Sec. III, 10 March 2001, no. 13739, B., in C.E.D. Cass., no. 249903

58. See Court of Cassation, Sec. IV, 4 February 2010, Giuliana, in C.E.D. Cass., no. 246803.

59. See L. Cricrì, 'Errore giudiziario (riparazione dell') (Diritto processuale penale)', in XIII Enciclopedia giuridica 2 (2007). 
Indeed, an unfailing corollary to the principle of procedural legality pursuant to Article 111 of the Constitution $^{60}$ is that a process can be deemed fair only to the extent that jurisdiction has been carried out in full compliance with the law. ${ }^{61}$

The link between 'procedural' injustice and wrongful conviction may be clearly perceived if we consider that the rules of the due process of law are functional to issuing a correct judgment in its cognitive outcome. ${ }^{62}$ Indeed, an unjust reconstructive method necessarily affects the formation of the judicial conviction and thus invalidates the outcome of the process. ${ }^{63}$ Therefore, even if it does not directly represent a remedial tool for cases of wrongful conviction of the kind represented by revision, it nevertheless seems appropriate to discuss the 'Extraordinary appeal by cassation due to a factual error' (Art. 625-bis CCP). ${ }^{64}$

This institute is the result of a recent evolution of the Italian procedural system, in which the traditional stability of the judicial decisions has become recessive with respect to the protection of the fundamental rights of the convicted. ${ }^{65}$ In particular, the 'Extraordinary appeal by cassation due to a factual error' aims to remove the final judgment when, because of a perceptual error, the convicted's right to a fair proceeding before the Court of Cassation has been infringed, causing a breach of a constitutionally guaranteed prerogative (the right to appeal to the Court of Cassation: Art. 111, para. 7, of the Constitution) and thus justifying the overcoming of the res judicata. ${ }^{66}$

60. Art. 111 of the Constitution: 'Jurisdiction shall be implemented through due process regulated by law. All court trials shall be conducted with adversary proceedings and parties shall be entitled to equal conditions before a third-party and impartial judge. ... In criminal law trials, the law shall establish that the accused be promptly and confidentially informed of the nature and reasons of the charges and be given adequate time and conditions to prepare a defence. A defendant shall have the right to cross-examine witnesses for the prosecution, or to have them cross-examined before a judge; examine witnesses for the defence in the same conditions as the prosecutor; and the right to produce any evidence for the defence. ... The formation of evidence in criminal law trials shall be based on an adversarial process. The guilt of the defendant may not be established on the basis of statements by persons who have willingly refused cross-examination by the defendant or the defendant's counsel. The law shall regulate the cases in which the formation of evidence may not occur in an adversarial process, with the consent of the defendant or owing to verified objective impossibility or proven illicit conduct. ...'

61. See A.A. Sammarco, 'Il ricorso straordinario per errore materiale o di fatto e la rescissione del giudicato', in G. Spangher (dir.), Procedura penale. Teoria e pratica del processo (2015) 385.

62. See G. Fiorelli, "Il ricorso straordinario per errore giudiziario "di fatto". Portata, estensione e limiti', in L. Lupária (ed.), L'errore giudiziario (2020) 525.

63. See G. Fiorelli, 'L'errore giudiziario "di fatto": portata applicativa e (dis)orientamenti giurisprudenziali', in L. Lupária, L. Marafioti \& G. Paolozzi (eds.), Errori giudiziari e background processuale (2017) 121, at 122.

64. Introduced by Law no. 128/2001 and later modified by Law no. $103 / 2017$.

65. See Lupária and Gialuz, above n. 2, at 70

66. See P. Troisi, 'Flessibilità del giudicato penale e tutela dei diritti fondamentali' (2 April 2005) in www.penalecontemporaneo.it/upload/ 1427127412TROISI_2015a.pdf (last visited 26 December 2020) at 6-7.
Pursuant to Article 625-bis CCP, 'the convicted person is allowed to submit a request for rectification of a ... factual error contained in the decisions delivered by the Court of Cassation'. ${ }^{67}$ Although the CCP does not specify the characteristics of the relevant factual error, both doctrine and jurisprudence have specified that it is a perceptive mistake that affects the essential content of the procedure; ${ }^{68}$ i.e. a misleading perceptual representation of reality that interfered with the judge's decisionmaking. ${ }^{69}$

The correction of the error is taken in charge by the Court of Cassation itself, to which the request can be presented by the Prosecutor General or by the convicted person within one hundred and eighty days of the filing of the decision; however, the error can also be detected ex officio by the Court within ninety days of delivering the decision. The effects of the latter can be suspended by the Court of Cassation in exceptionally serious cases. After assessing the admissibility of the request, also with respect to its non-manifest groundlessness, the Court examines the request in chambers and takes the necessary measures to correct the error.

Lastly, it should be noted that the Court of Cassation has stated that this remedy can also be proposed against the sentences issued by the Court itself when dealing with a request for revision. ${ }^{70}$ Therefore, one may request the correction of the factual error contained in the Court of Cassation's sentence declaring inadmissible, or rejecting, the convicted person's appeal against the negative decision of the Court of Appeal on the request for revision.

\subsection{The 'Rescission of Final Judgment'}

The 'Rescission of final judgment' (Art. 629-bis CCP) is another tool that, albeit indirectly, can act as a remedy for wrongful convictions. In fact, through such a request, any convicted person who has been absent for the entire duration of the proceeding may obtain the rescission of the final judgment if he can prove that his absence was due to an inculpable unawareness of the proceeding. The Court of Cassation has been very strict

67. The rule also provides for the possibility of remedying a 'clerical error'; the hypothesis, however, is outside the scope of this study. In doctrine, on the subject, see L. Marafioti, 'Correzione di errori materiali', VI Digesto delle discipline penalistiche 533 (1992).

68. See A. Capone, Gli errori della Cassazione e il diritto al controllo di legittimità (2005), at 141.

69. See, ex multis, Court of Cassation, Joint Chambers, 27 March 2002, Basile, in C.E.D. Cass., no. 221280 and Court of Cassation, Joint Chambers, 27 March 2002, De Lorenzo, in C.E.D. Cass., no 221278. For example, a factual error occurs if the Court of Cassation does not examine an argument proposed by the appellant (Court of Cassation, Sec. II, 18 June 2019, Lampada in C.E.D. Cass., no. 276925) or if the Court of Cassation errs in not declaring that the statute of limitations has expired (Court of Cassation, Sec. IV, 12 December 2014, Refatti, in C.E.D. Cass., no. 262028)

70. Court of Cassation, Joint Chambers, 21 July 2016, Nunziata, in C.E.D. Cass., no. 269788. In doctrine, see M. Gialuz, 'Un altro tassello nell'evoluzione del ricorso straordinario per cassazione: da rimedio eccezionale a valvola di chiusura del sistema delle impugnazioni', 5 Diritto penale contemporaneo 350 (2017) 
in assessing this requirement: ${ }^{71}$ in fact, such inculpable unawareness must be ruled out if the accused, during the investigation phase, has stated or chosen an address for service. In fact, according to the Court, if the address for service is set in the lawyer's office, the accused must keep in contact with his own lawyer on the developments of the proceeding; on the other hand, if the address for service is set in his own home, the accused should inform the Court of possible changes.

The request must be submitted, either in person or through a lawyer holding a special power of attorney, to the Court of appeal in whose district the decision was taken, within thirty days of the acknowledgment of the proceeding by the accused. If the Court of Appeal, which decides in chambers, accepts the request, it rescinds (i.e. revokes) the judgment and orders the case file to be forwarded to the first instance court (Art. 629bis, para. 2-3, CCP).

The institute represents a restorative post iudicatum remedy connected to the changes made by Law no. $67 / 2014$ in the Italian procedural system. Indeed, this legislation states that judges can proceed in the absence of the accused person, on the presumption that the latter has knowledge of the trial. ${ }^{72}$ Therefore, it was thought necessary to protect the convicted when proved, after the final judgment, that the presumed knowledge did not reflect the truth.

Unlike what happens in the revision, the rescission of final judgment does not in itself involve acquittal, but rather the celebration of a new trial in which the accused can fully exercise his right of defence. Keeping this in mind, it is possible to include the rescission of final judgment among the tools offered by the system as a 'mediated' remedy for miscarriages of justice, since the new judgment might end with the acquittal of the accused.

\section{Conclusion}

While the new remedies against 'procedural' injustice have significantly widened the possibility to remove final judgments, the process towards ascertaining an effective protection against 'substantial' errors is far from being accomplished.

71. See Court of Cassation, Sec. IV, 3 March 2020, Ginevra, in C.E.D. Cass. no. 278648, and Court of Cassation, Sec. II, 27 March 2019, Pinton, in C.E.D. Cass., no. 276972.

72. Art. 420-bis CCP: 'if the accused, free or detained is not present at the hearing and, even if unable to appear, has expressly waived his right to be present, the Preliminary Hearing Judge shall proceed in his absence. .. The Preliminary Hearing Judge shall also proceed in the absence of the accused if the latter has already declared or chosen an address for service during the proceedings or has been arrested or placed under temporary detention or has been ordered a precautionary measure or has appointed a retained lawyer. The Judge shall also proceed when the accused is not present at the hearing but has been served the notice of the hearing personally or it is in any case certain that the accused is aware of the proceedings or has voluntarily avoided to be informed about either the proceedings or the documents thereof'.
On the one side, the new 'European revision' provided by the Constitutional Court and the jurisprudential reconstructions interpreting the notion of new evidence in a broader sense have undoubtedly enlarged the scope of revision. On the other side, the Court of Cassation has weakened the potential for revision by stating that the new scientific evidence employed in the revision must deny the scientific validity of the knowledge implemented in the previous judgment. ${ }^{73}$

In this regard, some authors have stressed the necessity of the Italian legislature to 'take responsibility for making choices, doing a much-needed check-up of the traditional revision and, even more urgently, a complete codification of the European one' ${ }^{74}$

However, it would be illusory to think that an effective system of post-conviction remedies would be enough to solve the problem of miscarriage of justice. In fact, we must keep in mind that 'wrongful convictions are not usually isolated cases but rather reflect systemic problems' ${ }^{75}$

In this perspective, along the lines of the American experience, it would be advisable to create an Italian equivalent of the U.S. National Registry of Exonerations, ${ }^{76}$ providing detailed information on all the cases where final convictions were reversed in a revision trial. This tool would be extremely helpful for scholars to 'easily obtain the information and data they need to build their own theory on the causes of wrongful convictions, to advance reform proposals and to share awareness'. 77

Unfortunately, up to now, the Ministry of Justice is not required to provide official data concerning wrongful conviction cases, although the cooperation among national institutions would make the collection of data easier and, at the same time, would help to increase the awareness about the issue of miscarriages of justice. ${ }^{78}$

At the same time, and once more learning from the overseas experience, a new consciousness of the constant recurring of wrongful convictions would help in creating Conviction Integrity Units (C.I.U.), ${ }^{79}$ i.e. divisions of prosecutors' offices whose task is to prevent, identify and remedy wrongful convictions.

As has been pointed out, the Italian Prosecutors are already allowed by the CCP rules to ask for revision, yet this rarely happens in the practice. Hence, the need for a further 'cultural' step towards a better criminal system:

73. See supra, §5.2.

74. M. Gialuz, 'Il giudizio di revisione', in L. Lupária (ed.), L'errore giudiziario (2020) 567, at 638.

75. B. Garrett, Convicting the Innocent, Worldwide, in L. Lupária (ed.), L'errore giudiziario (2020) 1, at 15 .

76. The Italian Innocence Project is currently working to have an equivalent of the National Registry of Exonerations established in Italy: see M. Pittiruti, 'Le cause e i rimedi dell'errore giudiziario tra Europa e Stati Uniti' (17 November 2017), in https://archiviodpc.dirittopenaleuomo.org/d/ 5710-le-cause-e-i-rimedi-dell-errore-giudiziario-tra-europa-e-stati-uniti (last visited 26 December 2020)

77. Lupária and Greco, above n. 3, at 17

78. Lupária, above n. 33, at 4

79. A list of Conviction Integrity Units currently active in the United States is provided for by www.law.umich.edu/special/exoneration/Pages/ Conviction-Integrity-Units.aspx (last visited 26 December 2020). 
keeping in mind that 'the decrease in the number of wrongful convictions serves the purpose of justice, and not merely that of the defendant', ${ }^{80}$ prosecutors and lawyers should work side by side to provide an adequate implementation of Article 4, paragraph 4, of the Constitution, which can be obtained only through a prompt identification of causes and cases of wrongful convictions. 